\title{
Periódicos científicos brasileiros: visibilidade e charme
}

\section{Mauricio Rocha e Silva ${ }^{1}$}

Ao falarmos de nossos periódicos científicos é importante não esquecer que eles existem em duas categorias: com e sem peer review. Só a primeira deve ser levada em conta. Ao todo, segundo a CAPES, são cerca de seis mil, mas apenas $8 \%$ dentre eles publicam ciência original com peer review. Antes que alguém ache isso anormal, vale notar que o grande arquivo internacional Ulrich's relaciona cerca de 300.000 periódicos científicos em todo o mundo, dos quais apenas 27.000 são peer reviewed. Portanto, estamos na média mundial. Quanto à visibilidade, o divisor é outro: século passado e milênio novo. Até 1999, a maioria de nossos periódicos era totalmente invisível e apenas um punhado muito pequeno conseguia ter seus artigos citados. Nenhum periódico brasileiro jamais chegou a ter um fator de impacto acima de 1,000 e pouquíssimos chegavam a 0,500! A partir do novo milênio tudo mudou, graças ao SciELO e ao PubMed. A criação de uma biblioteca virtual de acesso livre e gratuito (SciELO) disponível no PubMed, passou a significar que qualquer pessoa no mundo conectada a Internet pode consultar e fazer o download de graça de qualquer artigo de nossos periódicos. Naturalmente, peer review é condição sine-qua-non para ser aceito no SciELO. A mágica não demorou muito. Em 2004, duas revistas brasileiras atingiram um Fator de Impacto acima de 1,000 e nunca mais voltaram para trás. Apenas seis anos mais tarde, temos uma revista com impacto acima de 2,000 e treze revistas acima de 1,000. Projeções para 2011 sugerem que teremos talvez duas revistas acima de 2,000 e algo em torno de quinze acima de 1,000. Os downloads de artigos científicos publicados em nossos periódicos saltaram de $100 \mathrm{mil}$ em 1999 para mais de 100 milhões em 2010.

Nossas revistas são visíveis e os artigos que nelas aparecem são lidos e citados como nunca foram. Sem dúvida estamos mais atraentes! Mas poderíamos estar muito mais charmosos! E infelizmente o obstáculo é interno. O sistema de avaliação de artigos publicados por nossos programas de pós-graduação não nos ajuda em nada. Qualquer aluno ou orientador de pós-graduação que publique numa revista brasileira sofre um desconto de 20 a 60\% na sua nota por ter publicado em casa. O sistema classificador de artigos baseia-se numa ideia perigosamente carregada de viés: o artigo recebe a nota em função do fator de impacto do periódico que o publica. Não somos os únicos pecadores: diversas agências internacionais, tanto de classificação como de distribuição de verbas também o cometem. O próprio pai do Fator de Impacto, Eugene Garfield, já fez essa observação: o fator de impacto reflete a importância dos periódicos, mas jamais a dos artigos ali publicados, porque a distribuição de citações pelos artigos é tremendamente assimétrica.

Em um estudo(1), recentemente publicado, examinei cerca de 7.000 artigos publicados em 60 periódicos com fatores de impacto entre 1 e 50 e observei que todos eles obedecem a uma distribuição tipo Princípio de Pareto: em sua forma original, o referido princípio afirma que em todas as atividades humanas, $80 \%$ das ações resultam de $20 \%$ dos agentes. No caso das citações em periódicos científicos a situação não é tão extrema; mas a assimetria é profunda: $50 \%$ das citações provem de $20 \%$ dos artigos (os mais citados) enquanto apenas $3 \%$ das citações provem dos $20 \%$ menos citados. Qual é a consequência dessa assimetria para o julgamento indireto dos artigos? Muito simples: não importa onde um artigo é publicado ele tem cerca de $30 \%$ de chance de ser mais citado e cerca de $60 \%$ de ser menos citado do que o fator de impacto da revista sugere. Se um autor consegue publicar na categoria mais alta do sistema de avaliação, ele certamente não será subavaliado porque já está recebendo a nota máxima. Mas tem $50 \%$ de chance de ser superavaliado, sorte dele! 0 problema é bem mais complicado se o artigo aparece numa das categorias abaixo da mais alta: neste caso, o nosso autor corre um risco nada desprezível (30\%) de ser subavaliado! Porque ele será mais citado do que sugere o fator de impacto da revista onde publica e deveria ganhar uma nota mais alta. Azar dele! A chance de superavaliação continua em $50 \%$ (sorte dele!) de modo que a avaliação será correta apenas para $20 \%$ dos artigos. Em diagnóstico isso tem um nome: Fator Preditivo Positivo (FPP) que define a porcentagem de avaliações corretas realizadas por qualquer teste diagnóstico. Qualquer sistema que avalie publicações científicas indiretamente através do fator de impacto do periódico tem um FPP de $40 \%$ para revistas da categoria mais alta e de $20 \%$ para as categorias inferiores. Ou seja, $60 \%$ de erro na categoria mais alta e $80 \%$ de erro nas inferiores!

Vamos agora aplicar este conceito às nossas revistas. No sistema de avaliação da pós-graduação brasileira, nenhuma revista brasileira pertence ao extrato mais alto: consequentemente, para todas elas vale o Fator

${ }^{1}$ Editor da Clinics. São Paulo, SP, Brasil. mrsilva36@hcnet.usp.br 
Preditivo Positivo de $20 \%$, o que quer dizer que $80 \%$ dos artigos ali publicados são avaliados incorretamente! Para $50 \%$ dos casos, vale o conceito sorte deles, mas cerca de $30 \%$ são rebaixados em suas notas. Um dos argumentos usados por todas as instituições avaliadoras é que para artigos recentemente publicados é impossível avaliar corretamente quantas citações Ihe serão atribuídas. Consideremos um exemplo absolutamente extremo: quantas citações terá recebido em junho deste ano um artigo publicado em dezembro de 2011? Com quase certeza, nenhuma, quer ele seja publicado num periódico de impacto 1, 5 ou 50 ! Mas se o recuo for um pouco maior, digamos de junho de 2011 para junho de 2012, ele já estará visível e possivelmente citado. A ideia nova é usar um procedimento recém-proposto, que batizei de Continuously Variable Rating ${ }^{(1)}$. A ideia velha, não nos esqueçamos, tem $80 \%$ de probabilidade de produzir um resultado errado.

Antes que alguém pense que o meu propósito é totalmente negativo, faço questão de frisar o que tenho dito repetidamente: o que o Brasil deve à CAPES não tem preço. Cientificamente, somos o que somos, um dos países G20 da ciência, graças à vontade política e a tudo o que a CAPES tem feito por este país. Há 70 anos éramos um anão científico que olhava para a Argentina com longos olhares de inveja. Hoje produzimos tanta ciência quanto a soma de México, Argentina, Chile, e todos os demais países latino-americanos! Muito disso deve-se ao sistema de pós-graduação CAPES, ao portal CAPES e à dinâmica CAPES. Vamos, pois, continuar torcendo para que a CAPES corrija esta sua insólita inconsistência, que destoa tanto do resto da CAPES quanto a falta de um dente da frente destoa numa beldade total!

\section{Referência}

1. Rocha-e-Silva M. Continuously Variable Rating: a new, simple and logical procedure to evaluate original scientific publications. Clinics. 2011;66(12):2099-104. 